\title{
Magnetic Mineralogical Characteristics of Hamersley Iron Ores in Western Australia
}

\author{
William W. Guo \\ School of Engineering \& Technology, Central Queensland University, North Rockhampton, Australia \\ Email: w.guo@cqu.edu.au
}

Received 3 November 2014

\begin{abstract}
This paper presents the research outcomes of a magnetic mineralogical study on Hamersley iron ores. Thermal magnetic analysis shows that typical high-grade martite-microplaty hematite or M( $\mathrm{mpl} \mathrm{H})$ and martite-microplaty hematite-goethite or $\mathrm{M}-(\mathrm{mpl} \mathrm{H})$-g ores contain a small amount of original magnetite. A small amount of magnetite/maghemite and pyrite/pyrrhotite/siderite may exist in typical martite-goethite (M-G) and martite-ochreous goethite (M-oG) ores. In "the hardcap zone", M-(H)-g ores contain a small amount of magnetite and maghemite. Compared with XRD, thermal magnetic analysis is not only more sensitive in identifying trace of magnetite contained in high-grade hematite ores, but also more diagnostic in identifying other unstable magnetic minerals like maghemite and pyrite/pyrrhotite/siderite co-existed in the ores.
\end{abstract}

\section{Keywords}

Thermal Magnetic Analysis, Hamersley Iron Ores, Ferromagnetic Minerals, Hamersley Province

\section{Introduction}

The Hamersley Province in the southern Pilbara is situated in the northwest of Western Australia, approximately $1000 \mathrm{~km}$ north of Perth. The province contains extensive banded iron formations (BIFs) and large iron-ore deposits, consisting predominantly of hematite/martite and goethite, and contains approximately $10 \%$ of the world's known reserves of iron ore [1]. Study on magnetism of iron ores and rocks in this region has a profound impact on exploration of new iron ore deposits [2] [3], understanding the genesis of iron ore formation [4]-[6], magnetic mineralogy [7]-[9], and potentially iron ore grade control in mining [10].

Some studies relevant to magnetism in the region were conducted since 1968, mainly focused on palaeomagnetism [4]-[6] [11] [12] and magnetic petrophysics for iron ore exploration [13]. This paper presents the research outcomes of a magnetic mineralogical investigation on Hamersley iron ores. This is the first time that a systematic thermal magnetic approach was used to identify magnetic mineral combinations of different iron ores in the region. Compared with other methods such as XRD, this approach was proven not only more sensitive to trace of magnetite contained in high-grade hematite ores, but also more diagnostic in identifying other unstable magnetic minerals co-existed in the ores. This new finding leads to a better understanding of Hamersley iron ores classification established through traditional geological, geochemical, and mineralogical models [14]-[16].

In the following sections, Hamersley iron ores are firstly described and followed by the thermal magnetic ex- 
periments conducted on the typical Hamersley iron ores selected from samples taken from some mines in the Hamersley Province in Western Australia. Discussions will then be made based on comparison between the results from this study and existing data so as to achieve a better understanding of the iron ores in the Hamersley Province. Conclusions will be drawn from this study at the end of this paper.

\section{Classification of Hamersley Iron Ores}

Hamersley iron ores have been described by many geologists [14]-[16]. These have led to the establishment of a comprehensive Pilbara Iron Ore Classification (PIOC), mainly based on mineralogical and chemical studies. A simplified iron ore classification, derived from [16], is used for this study (Figure 1).

Those ores essentially free of goethite are called martite-microplaty hematite ore or $\mathrm{M}$-(mpl H) ore. The microplaty form of hematite is a diagnostic feature of these ores. Typical examples of these ores occur at Tom Price and Whaleback mines, so these ores are also named the TP/W Ore Type. Microplaty hematite ores in which significant goethite is present are termed the martite-microplaty hematite-goethite ore or M-(mpl H)-g ore. The Paraburdoo mine is typical for these ores so it is also named the Paraburdoo Ore Type.

Goethite rich ores, in general, are divided into two types, the Martite-Goethite type (M-G) ores, and the Martite-ochreous Goethite type (M-oG) ores which contain significant levels of ochreous goethite. In ores from the upper levels of M-G or M-oG deposits or "the hardcap zone", there are significant proportions of massive secondary hematite $(\mathrm{H})$ that have resulted from the dehydration of goethite. Ores of this type are shown as M-(H)-g.

\section{Thermal Magnetic Experiments}

\subsection{Principles of Thermal Magnetic Analysis}

The Curie temperature, at which the magnetic ordering of a mineral is destroyed [17], is the benchmark for identifying magnetic minerals. The general features of the Curie temperature for some common magnetic minerals are given in Table 1 [18] [19]. However, it should be noted that the Curie temperature of a magnetic mineral may be affected by the presence of impurities [20]. The heating of a sample may induce chemical changes in its magnetic, and sometimes non-magnetic, minerals, and results in the generation and destruction of magnetic minerals at certain temperatures. Some possible thermal chemical reactions involving magnetic minerals are summarized in Table 2 [18] [19]. These chemical reactions can also be used for identifying the magnetic and sometimes non-magnetic minerals in a rock.

Table 1. Some generalised properties of ferromagnetic minerals.

\begin{tabular}{cccc}
\hline Minerals & Composition & Curie/Neel temperature $\left({ }^{\circ} \mathrm{C}\right)$ & Mass susceptibility $\left(\times 10^{-8} \mathrm{SI} / \mathrm{kg}\right)$ \\
\hline Magnetite & $\mathrm{Fe}_{3} \mathrm{O}_{4}$ & $575-580$ & 578 \\
Maghemite & $\gamma-\mathrm{Fe}_{3} \mathrm{O}_{4}$ & unstable & 500 \\
Hematite & $\alpha-\mathrm{Fe}_{2} \mathrm{O}_{3}$ & $675-680$ & 25 \\
Goethite & $\gamma-\mathrm{FeOH}$ & $120-130$ & $0.5-1.5$ \\
Pyrrhotite & $\mathrm{Fe} 7 \mathrm{~S} 8$ & 320 & $0.1-20$ \\
\hline
\end{tabular}

Table 2. Thermochemical reactions involving magnetic minerals.

\begin{tabular}{ccc}
\hline Initial mineral & Alteration product & Converting temperature $\left({ }^{\circ} \mathrm{C}\right)$ \\
\hline Maghemite & Hematite & $350-450$ \\
Pyrrhotite & Magnetite & $>500$ \\
Pyrite & Magnetite & $350-500$ \\
Lepidocrocite & Maghemite & $220-270$ \\
Goethite & Hematite & $200-400$ \\
Siderite & Magnetite & $>200$ \\
\hline
\end{tabular}




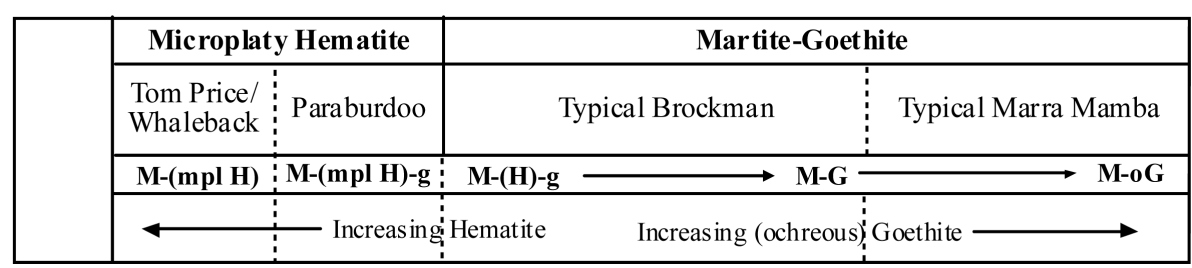

Figure 1. Hamersley iron-ore classification used in this study.

Low-field magnetic susceptibility of powders of selected iron ores was measured using a Bartington MS2 susceptibility/anisotropy system. The powders were not sealed in a vacuum container during both heating and cooling stages so as to observe the difference between demagnetization and remagnetization of unstable magnetic minerals contained in the ore samples during the experiment. The maximum heating temperature was set at $710^{\circ} \mathrm{C}$. Thermal susceptibility measurements were operated within a magnetic shield.

\subsection{Hematite/Martite}

Most $\mathrm{M}$-(mpl H) and M-(mpl H)-g ores are dominated by hematite/martite. In the $\kappa$-T curve of sample NM03 (Figure 2), the sharp changes in susceptibility occurring around $675^{\circ} \mathrm{C}$ in both heating and cooling curves indicate the presence of hematite/martite, whereas the small variations in susceptibility around $570^{\circ} \mathrm{C}$ show the existence of a trace of magnetite in this ore sample.

\subsection{Hematite/Martite + Magnetite}

Figure 3 shows an ore sample containing both hematite/martite and magnetite. In the $\kappa$-T curves of samples TP06, the two drops in susceptibility at temperatures of $\sim 570^{\circ} \mathrm{C}$ and $\sim 670^{\circ} \mathrm{C}$ correspond to the Curie temperatures of magnetite and hematite/martite, respectively. The magnetite is the residue of original magnetite in BIF that has not been completely oxidised to hematite/martite.

\subsection{Magnetite + Maghemite (+ Hematite/Martite)}

Figure 4 shows a "hard cap" ore sample consisting of magnetite, maghemite and hematite/martite. The first decrease in susceptibility in the temperature range $300^{\circ} \mathrm{C}$ to $350^{\circ} \mathrm{C}$ may indicate the presence of maghemite and its conversion to hematite. The drops in susceptibility around $570^{\circ} \mathrm{C}$ correspond to the Curie temperature of magnetite. Weak drops in susceptibility appear at $\sim 680^{\circ} \mathrm{C}$ indicating the presence of hematite/martite, but this is not as evident as magnetite.

\subsection{Pyrrhotite/Pyrite/Siderite + (Magnetite) + Hematite/Martite}

For Martite-ochreous Goethite (M-oG) ores, the sharp susceptibility increases at temperatures of $400^{\circ} \mathrm{C}$ to $550^{\circ} \mathrm{C}$ in the heating curves, shown on Figure 5, may indicate the chemical conversion of pyrite/pyrrhotite or siderite to magnetite. The subsequent immediate drops in susceptibility after $550^{\circ} \mathrm{C}$ indicate the Curie temperature of magnetite (either primary or secondary). There is no strong show of existence of hematite/martite in this curve, but the ore is actually dominated by $90 \%$ of hematite/martite in weight. It is just because the magnetism produced by a few percentage of primary or secondary magnetite in the ore is so strong that the magnetism produced by hematite/martite is completely compressed. When using M-oG ores with $98 \%$ of hematite/martite in weight for the experiment, magnetic effect of hematite/martite appears, shown in Figure 6.

\section{Discussion}

\subsection{Comparison between XRD and Thermal Magnetic Analysis}

Table 3 shows the sensitivity of both XRD and thermal magnetic analyses for identifying ferromagnetic minerals contained in typical Hamersley iron ores. Both are able to identify hematite/martite because of its dominance in all three types of ores. XRD is superb in detecting goethite but thermal magnetic analysis completely fails in detecting goethite in the ores. On the other hand, thermal magnetic analysis is able to indicate existence of small amount of magnetite, maghemite and pyrite/pyrrhotite/siderite in some ores but XRD fails to do so. 


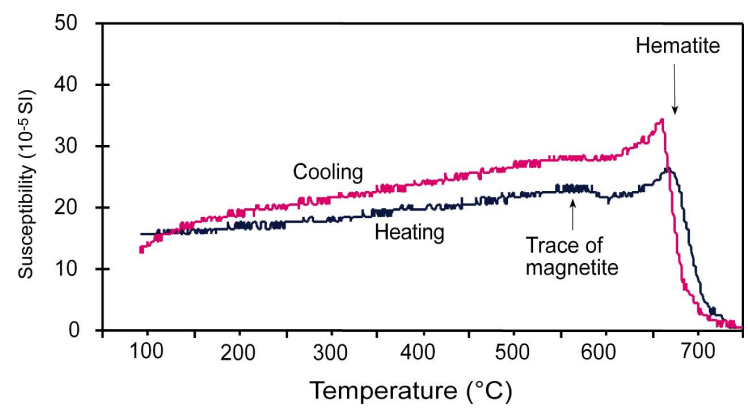

Figure 2. Thermal susceptibility curve of $\mathrm{M}-(\mathrm{mpl} \mathrm{H})$ ore.

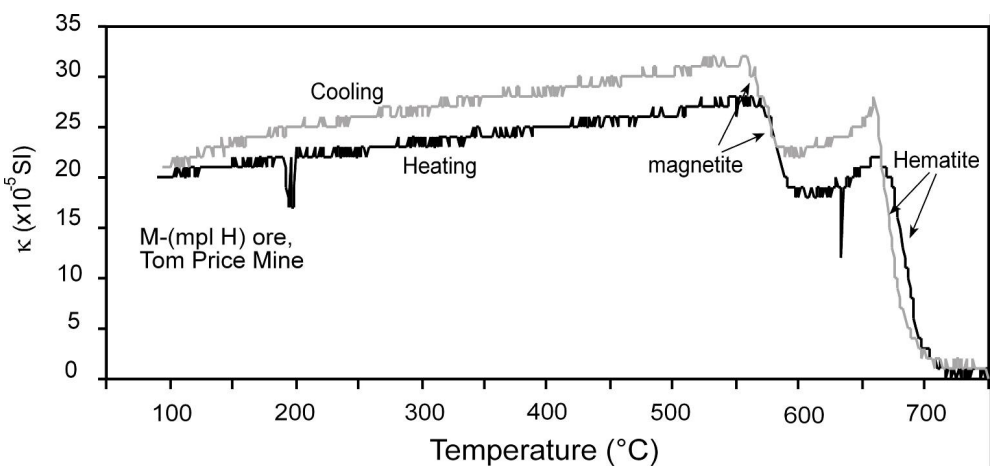

Figure 3. Thermal susceptibility curve of M-(mpl H)-g ore.

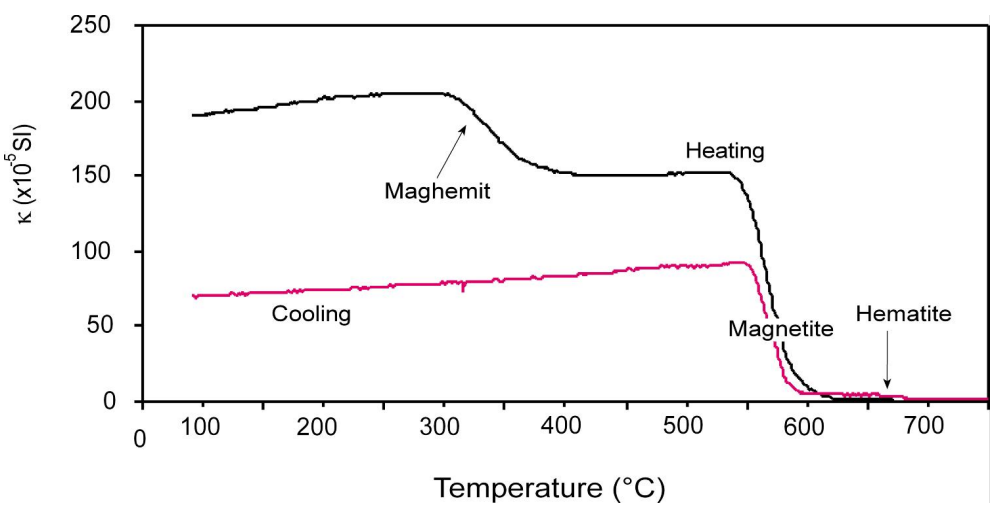

Figure 4. Thermal susceptibility curve of ‘hard cap’ M-(H)-g ore.

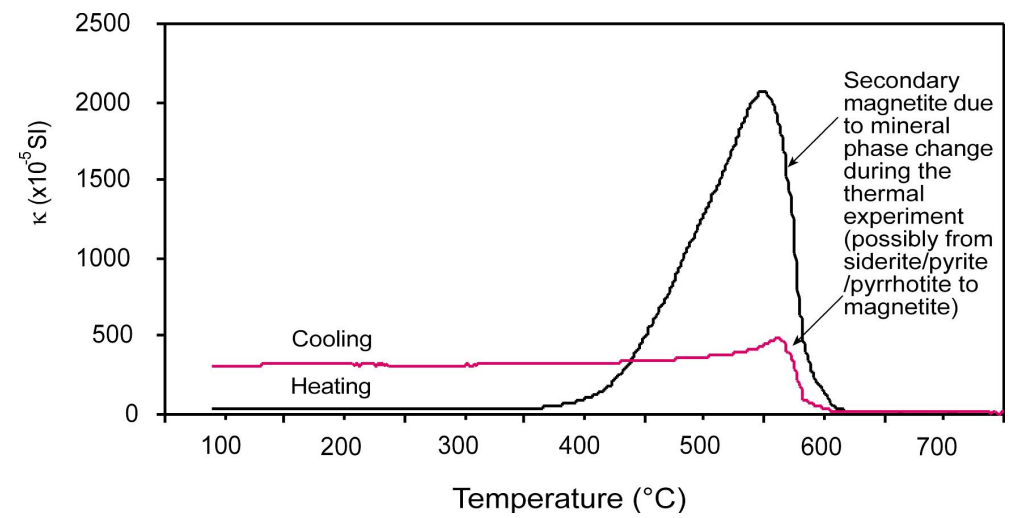

Figure 5. Thermal susceptibility curve of M-oG ore with some pyrite/ pyrrhotite or siderite. 


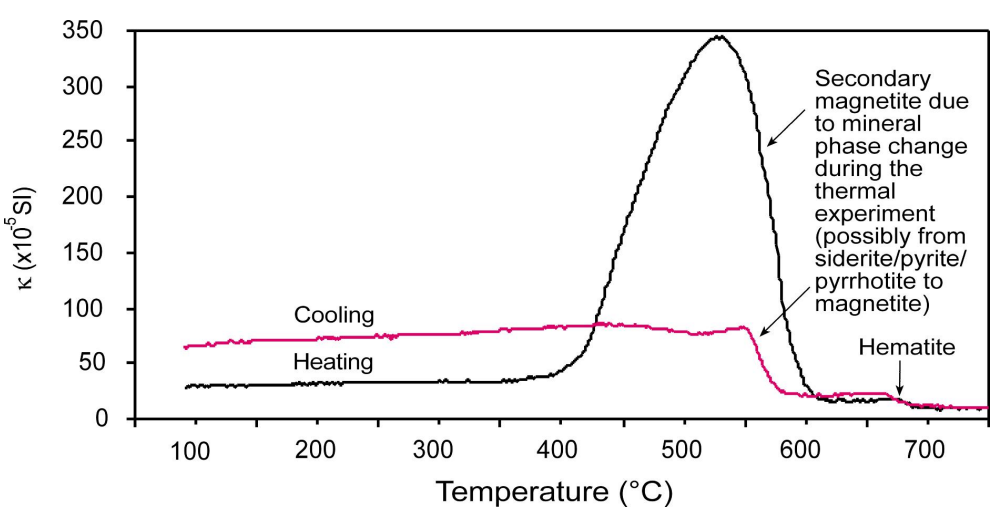

Figure 6. Thermal susceptibility curve of M-oG ore with a small amount of pyrite/pyrrhotite or siderite.

Table 3. XRD and thermal magnetic analysis in identifying ferromagnetic minerals in Hamersley iron ores.

\begin{tabular}{ccccccc}
\hline & \multicolumn{2}{c}{ M-(mpl H)-g ore } & M-(H)-g ore & \multicolumn{2}{c}{ M-oG ore } \\
\hline & XRD & Thermal magnetic & XRD & Thermal magnetic & XRD & Thermal magnetic \\
\hline Magnetite & $\mathrm{N}$ & $\mathrm{Y}$ & $\mathrm{N}$ & $\mathrm{Y}$ & $\mathrm{N}$ & $\mathrm{N}$ \\
Maghemite & - & - & $\mathrm{N}$ & $\mathrm{Y}$ & - & - \\
Hematite & $\mathrm{Y}$ & $\mathrm{Y}$ & $\mathrm{Y}$ & $\mathrm{Y}$ & $\mathrm{Y}$ & $\mathrm{Y}$ \\
Goethite & $\mathrm{Y}$ & $\mathrm{N}$ & $\mathrm{Y}$ & $\mathrm{N}$ & $\mathrm{Y}$ & $\mathrm{N}$ \\
Pyrrhotite/Pyrite/Siderite & - & - & - & - & $\mathrm{N}$ & $\mathrm{Y}$ \\
\hline
\end{tabular}

\subsection{Contribution to Hamersley Iron Ore Classification}

The results of thermal magnetic analysis show the dominance of hematite/martite in M-(mpl H)/M-(mpl H)-g ores, and also indicate the common presence of a small amount of magnetite. Strength of susceptibility of magnetite is about 200 times stronger than that of hematite [1]. Thus, when both magnetite and hematite are present, where magnetite is even between $0.1-0.5 \mathrm{wt} \%$, magnetic signature of magnetite will be clearly exhibited. Therefore, a very small fraction of magnetite in $\mathrm{M}-(\mathrm{mpl} \mathrm{H}) / \mathrm{M}-(\mathrm{mpl} \mathrm{H})$-g ores can make a significant contribution to the magnetic properties of iron ores. This is also applicable to $\mathrm{M}-(\mathrm{H})-\mathrm{g} / \mathrm{M}-\mathrm{G} / \mathrm{M}-\mathrm{oG}$ ores, which also contain a small amount of magnetite and maghemite. It is also noticeable that iron sulphides such as pyrite and pyrrhotite are present in some of the ores, particularly goethite-rich ores.

\section{Conclusions}

This thermal magnetic analysis indicates that a trace or a small amount of original magnetite exists commonly in typical high-grade martite-microplaty hematite or $\mathrm{M}$-( $\mathrm{mpl} \mathrm{H})$ ores and martite-microplaty hematite-goethite or M-(mpl H)-g ores in the Hamersley Province. Typical martite-goethite (M-G) and martite-ochreous goethite (M-oG) ores contain a small amount of magnetite, and pyrite/pyrrhotite/siderite. In the upper levels of M-G or M-oG deposits or "the hardcap zone", M-(H)-g ores contain a small amount of magnetite and maghemite.

Thermal magnetic analysis can identify a small amount of magnetite, maghemite and pyrite/pyrrhotite/siderite in different ores, of which XRD is incapable of finding. However, thermal magnetic analysis cannot detect goethite in the ores, at which XRD is good.

\section{Acknowledgements}

The Minerals \& Energy Research Institute of WA (MERIWA), BHP Iron Ore, Hamersley Iron, and Robe River Iron Associates are thanked for partly supporting this research. This study was supported by an Overseas Postgraduate Research Scholarship of Commonwealth Government of Australia, and a UWA University Postgraduate Award. Guidance from Professors ZX Li and C Powell was much appreciated. 


\section{References}

[1] Guo, W. (1999) Magnetic Petrophysics and Density Investigations of the Hamersley Province, Western Australia: Implications for Magnetic and Gravity Interpretation. The University of Western Australia, Perth.

[2] Guo, W., Dentith, M.C., Bird, R.T. and Clark, D.A. (2001) Systematic Error Analysis of Demagnetisation and Implications for Magnetic Interpretation. Geophysics, 66, 562-570. http://dx.doi.org/10.1190/1.1444947

[3] Guo, W.W., Li, Z.X. and Dentith, M.C. (2011) Magnetic Petrophysical Results from the Hamersley Basin and Their Implications for Interpretation of Magnetic Surveys. Australian Journal of Earth Sciences, 58, 317-333. http://dx.doi.org/10.1080/08120099.2011.552984

[4] Li, Z.X., Powell, C.M. and Bowman, R. (1993) Timing and Genesis of Hamersley Iron-Ore Deposits. Exploration Geophysics, 24, 631-636. http://dx.doi.org/10.1071/EG993631

[5] Powell, C.M., Oliver, N.H.S., Li, Z.X., Martin, D.M. and Ronaszeki, J. (1999) Synorogenic Hydrothermal Origin for Giant Hamersley Iron Oxide Ore Bodies. Geology, 27, 175-178. http://dx.doi.org/10.1130/0091-7613(1999)027<0175:SHOFGH>2.3.CO;2

[6] Li, Z.X., Guo, W. and Powell, C.M. (2000) The Timing and Genesis of the Hamersley Iron Ore Deposits: A New Palaeomagnetic Approach. Minerals and Energy Research Institute of Western Australia (MERIWA), Report M242.

[7] Guo, W.W., Li, M.M., Whymark, G. and Li, Z.X. (2009) Mutual Complement between Statistical and Neural Network Approaches for Rock Magnetism Data Analysis. Expert Systems with Applications, 36, 9678-9682. http://dx.doi.org/10.1016/j.eswa.2008.11.045

[8] Guo, W.W., Li, M.M., Li, Z.X. and Whymark, G. (2010) Approximating Nonlinear Relations between Susceptibility and Magnetic Contents in Rocks Using Neural Networks. Tsinghua Science \& Technology, 15, 281-287. http://dx.doi.org/10.1016/S1007-0214(10)70062-6

[9] Guo, W.W. A Study of Rock Magnetism of High-Grade Hematite Ores. Journal of Applied Mathematics and Physics. (In Press)

[10] Guo, W.W. (2010) A Novel Application of Neural Networks for Instant Iron-Ore Grade Estimation. Expert Systems with Applications, 37, 8729-8735. http://dx.doi.org/10.1016/j.eswa.2010.06.043

[11] Porath, H. and Chamalaun, F.H. (1968) Palaeomagnetism of Australian Haematite Ore Bodies II, Western Australia. Geophysical Journal of the Royal Astronomical Society, 15, 253-264. http://dx.doi.org/10.1111/j.1365-246X.1968.tb00184.x

[12] Schmidt, P. and Clark, D.A. (1994) Palaeomagnetism and Magnetic Anisotropy of Proterozoic Banded-Iron Formations and Iron Ores of the Hamersley Basin, Western Australia. Precambian Research, 69, 133-155. http://dx.doi.org/10.1016/0301-9268(94)90083-3

[13] Clark, D.A. and Schmidt, P. (1986) Magnetic Properties of the Banded-Iron Formations of the Hamersley Group, WA. CSIRO Division of Mineral Physics, AMIRA Report 1638.

[14] Kneeshaw, M. (1984) Pilbara Iron Ore Classification-A Proposal for a Common Classification for BIF-Derived Supergene Iron Ore. Proceedings of Australasian Institute of Mining and Metallurgy, 157-162.

[15] Morris, R.C. (1985) Genesis of Iron Ore in Banded Iron-Formation by Supergene and Supergene-Metamorphic Processes-A Conceptual Model. Handbook of Strata-Bound and Stratiform Ore Deposits, Elsevier, 73-235.

[16] Harmsworth, R.A., Kneeshaw, M., Morris, R.C., Robinson, C.J. and Shrivastava, P.K. (1990) BIF-Derived Iron Ores of the Hamersley Iron Basin. Geology of Mineral Deposits of Australia and Papua New Guinea, 617-642.

[17] Merrill, R.T., McElhinny, M.W. and McFadden, P.L. (1996) The Magnetic Field of the Earth: Paleomagnetism, the Core, and the Deep Mantle. Academic Press, San Diego.

[18] Tarling, D.H. and Hrouda, F. (1993) The Magnetic Anisotropy of Rocks. Chapman \& Hall, London.

[19] Dunlop, D.J. and Ozdemir, O. (1997) Rock Magnetism. Cambridge University Press, Cambridge. http://dx.doi.org/10.1017/CBO9780511612794

[20] Thompson, R. and Oldfield, E. (1986) Environmental Magnetism. Allen and Unwin, London. http://dx.doi.org/10.1007/978-94-011-8036-8 